\title{
Ambient sound as a cue for navigation by the pelagic larvae of reef fishes
}

\author{
Nick Tolimieri ${ }^{1,2, *}$, Andrew Jeffs ${ }^{3}$, John C. Montgomery ${ }^{1}$ \\ ${ }^{1}$ Experimental Biology Research Group, School of Biological Sciences, University of Auckland, Private Bag 92019, \\ Auckland, New Zealand \\ ${ }^{2}$ Leigh Marine Laboratory, PO Box 349, Warkworth, New Zealand \\ ${ }^{3}$ National Institute of Water and Atmospheric Research, PO Box 109695, Auckland, New Zealand
}

\begin{abstract}
Sound is a potentially important navigational cue for organisms in aquatic environments. Most reef fishes produce pelagic larvae that must locate suitable settlement habitat for the completion of their life-cycle. We used light traps and underwater loudspeakers to determine whether reef fish larvae are attracted to sounds produced on a reef. 'Sound traps' caught more triplefin (a benthic reef fish) larvae than did 'silent traps', demonstrating that the larvae of some reef fishes may use sound as a navigational cue in the field. Catches of pilchard larvae, a pelagic fish, did not vary between treatments. These results are the first demonstration, of which we are aware, of sound as a potential navigational cue in the aquatic environment.
\end{abstract}

KEY WORDS: Reef fish · Larvae - Sound - Orientation · Navigation · Light traps

Resale or republication not permitted without written consent of the publisher

Animals are capable of amazing feats of migration and navigation. Directed long-distance migrations occur in animals as diverse as sea turtles (Bowen et al. 1989), monarch butterflies (Hobson 1998), birds (Berhold 1991), marine snails (Hamilton \& Russell 1982), spiny lobsters (Herrnkind \& Kanciruk 1978), whales (Swartz et al. 1987) and salmon (McKeown 1984). The mechanisms of animal migration include the use of magnetic, celestial, and olfactory cues. Despite its potential importance, the use of ambient sound as a navigational cue has, to our knowledge, rarely been investigated and has never previously been clearly isolated as an orientation mechanism (Popper \& Carlson 1998).

Many reef fishes produce pelagic larvae that develop in the open water from days to weeks prior to returning to the benthos (Sale 1980, Leis 1991), a com-

*E-mail: n.tolimieri@auckland.ac.nz plex life-cycle common in the marine environment (Thorson 1950, Roughgarden et al. 1988). Settlement by these free-swimming larvae onto the reef habitat is a critical step in the life-cycle of reef fishes. During this step, fish larvae do not appear to be passive particles. They are excellent swimmers, capable of swimming from $10 \mathrm{~s}$ of $\mathrm{km}$ up to $90+\mathrm{km}$ non-stop at speeds great enough to overcome currents (Leis \& Carson-Ewart 1997, Stobutzki \& Bellwood 1997). Work on the Great Barrier Reef has shown that larvae can detect reefs from distances of at least $1 \mathrm{~km}$ (Leis et al. 1996). They move off-shore during the day (Leis et al. 1996), probably to avoid reef-based predation from visual predators. When they are developmentally ready, they actively move on-shore at night to settle to the reef habitat (Stobutzki \& Bellwood 1998). Recent evidence shows that they can settle to their natal reef to some extent (Jones et al. 1999, Swearer et al. 1999). The cues that these larvae use to locate and move toward reefs remain unknown.

Underwater sound is one cue that reef fish larvae may use to orient to reefs. Compared to other potential cues, such as visual and olfactory cues, sound is transmitted long distances through water with little attenuation and is highly directional (Rogers \& Cox 1988, Richardson et al. 1995). Reefs can be especially noisy, with much of the sound being biological in origin (Tait 1962, Cato 1980). Nocturnal activity by snapping shrimp, fish and urchins creates an 'evening chorus' on both rocky and coral reefs (Tait 1962, Cato 1980, Myrberg et al. 1986, Lobel 1992, McCauley 1994, 1995), including those in New Zealand (Tait 1962). Here we report the results of a field experiment testing the response of fish larvae to reef-generated noise. 
Methods. We used light traps (Doherty 1987) and underwater loudspeakers to determine whether fish larvae were attracted to sound emanating from a reef. Many fish larvae are attracted to light and generally settle at night (but see Leis \& Carson-Ewart 1999), making light traps excellent (but selective) tools for their collection. Our light trap design follows that of Sponaugle \& Cowen (1994) (Fig. 1). A separate watertight barrel housed a $12 \mathrm{~V}$ marine battery, amplifier and portable cassette player. An underwater loudspeaker (Lubell Labs Inc., LL964, 200 to $20 \mathrm{kHz}, 180 \mathrm{~dB}$ at $1 \mathrm{~m}$, reference sound pressure $1 \mu \mathrm{Pa}$ ) was suspended under the barrel. Traps and the loudspeaker were suspended $\sim 2 \mathrm{~m}$ below the surface.

We recorded ambient reef sound at night when reef fish larvae generally settle. Ambient underwater sound recordings were taken approximately $200 \mathrm{~m}$ offshore of the southern side of Ti Point Reef $\left(36^{\circ} 19^{\prime} \mathrm{S}, 174^{\circ} 48^{\prime} \mathrm{E}\right)$ in $14 \mathrm{~m}$ water depth (Fig. 2). We made calibrated digital sound recordings with a Sonatech 8178 hydrophone lowered to a depth of $8 \mathrm{~m}$ from the surface. The frequency spectra of the digital recordings were analysed using Canary software (Charif et al. 1995). A 3 min segment of the digital recording of Ti Point Reef was transferred directly to a 3 min TDK endless cassette (EC-3M) ready for play back.

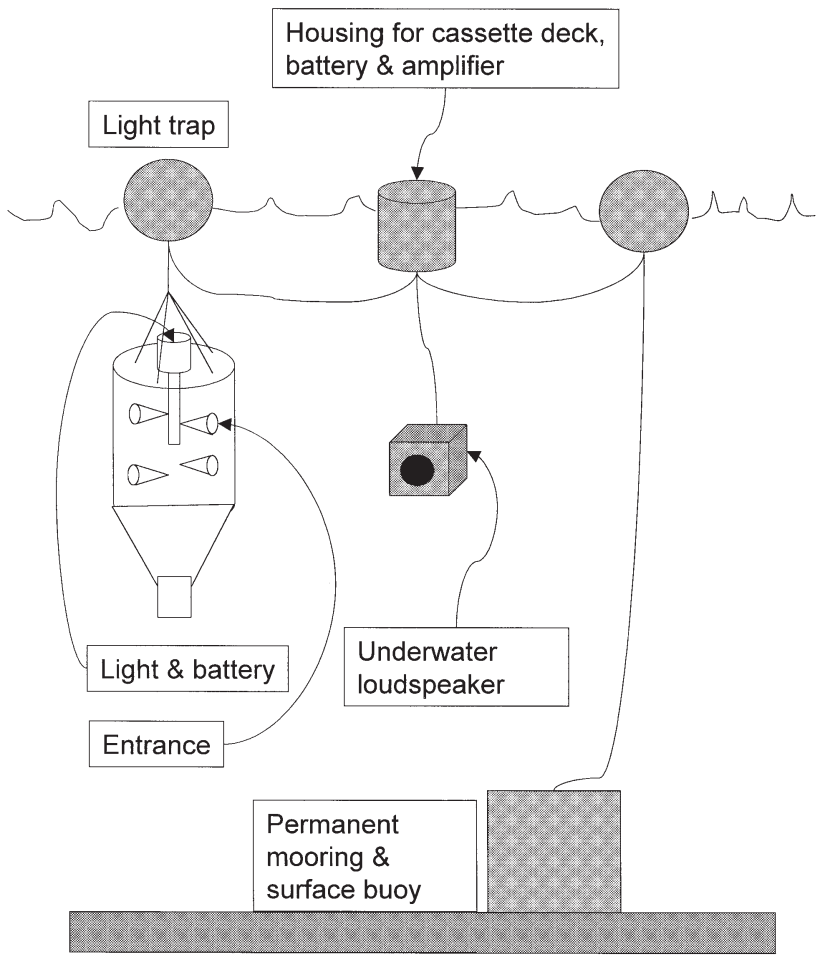

Fig. 1. Experimental apparatus showing configuration of the light trap and underwater sound playback equipment. The 'silent' control traps included a 'dummy' surface barrel but no loudspeaker. Drawing not to scale
Light traps were deployed overnight in 2 pairs (Fig. 2). One trap in each pair played back the recorded reef sound, while the other was a silent control. We established 4 permanent moorings in Omaha Bay, New Zealand $\left(36^{\circ} 20^{\prime} \mathrm{S}, 174^{\circ} 48^{\prime} \mathrm{E}\right)$ in $\sim 10 \mathrm{~m}$ of water. The moorings were arranged in pairs, with 1 pair placed further back in the bay. Paired traps were $\sim 500 \mathrm{~m}$ apart and at least $500 \mathrm{~m}$ from shore or the nearest reef and over a sand bottom. On each deployment, we randomly assigned a treatment (sound/ silent) to the first mooring. We then alternated treatments between moorings such that there was always 1 sound treatment in the front and back, and 1 sound treatment on either side of the bay. We deployed all the experimental apparatus about $1 \mathrm{~h}$ before sunset and collected the equipment and cleared the traps the following morning. Sampling was repeated on 14 nights from 19 August to 2 November 1999 when weather permitted.

We could not use parametric statistics to analyse the data because of high variance and non-normal distributions. Instead, we used 2 alternate approaches. First, we paired traps within nights and used a Wilcoxon

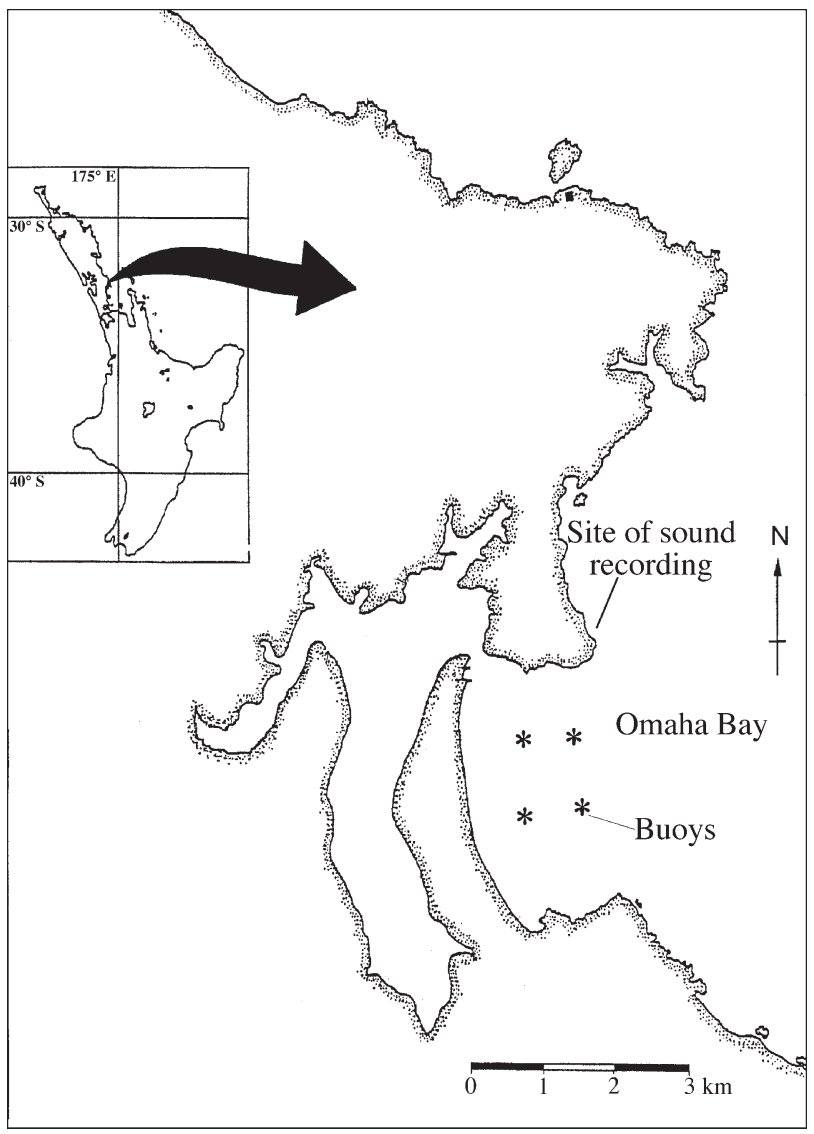

Fig. 2. Location of study site. Sound recordings were made at Ti Point $\left(36^{\circ} 19^{\prime} \mathrm{S}, 174^{\circ} 48^{\prime} \mathrm{E}\right)$ approximately $50 \mathrm{~m}$ from shore and $1 \mathrm{~m}$ above a rocky reef 
signed-ranks test. This approach maintains some information about the amount of difference in catch between pairs but analyses only rankings of the differences in size not the absolute size of the difference (Sokal \& Rohlf 1995). However, because larvae may travel in patches, we also wanted to analyse the data in a way that would not be potentially biased by large patches of larvae passing one trap but not another. We used $G$-tests to compare the number of times a sound trap caught more larvae than its silent partner. Here, the null hypothesis is that sound traps should catch more larvae than silent traps only $50 \%$ of the time (at random). For triplefin larvae, we used a KolmogorovSmirnov test to compare size distributions of larvae between treatments for data pooled across nights. We also compared median size between treatments and among nights using the Scheirer-Ray-Hare extension of the Kruskal-Wallis test (Sokal \& Rohlf 1995). We chose this test instead of analysis of variance because data were non-normal. Data from Night 11 could not be used due to loss of silent samples after counting but prior to measurement.
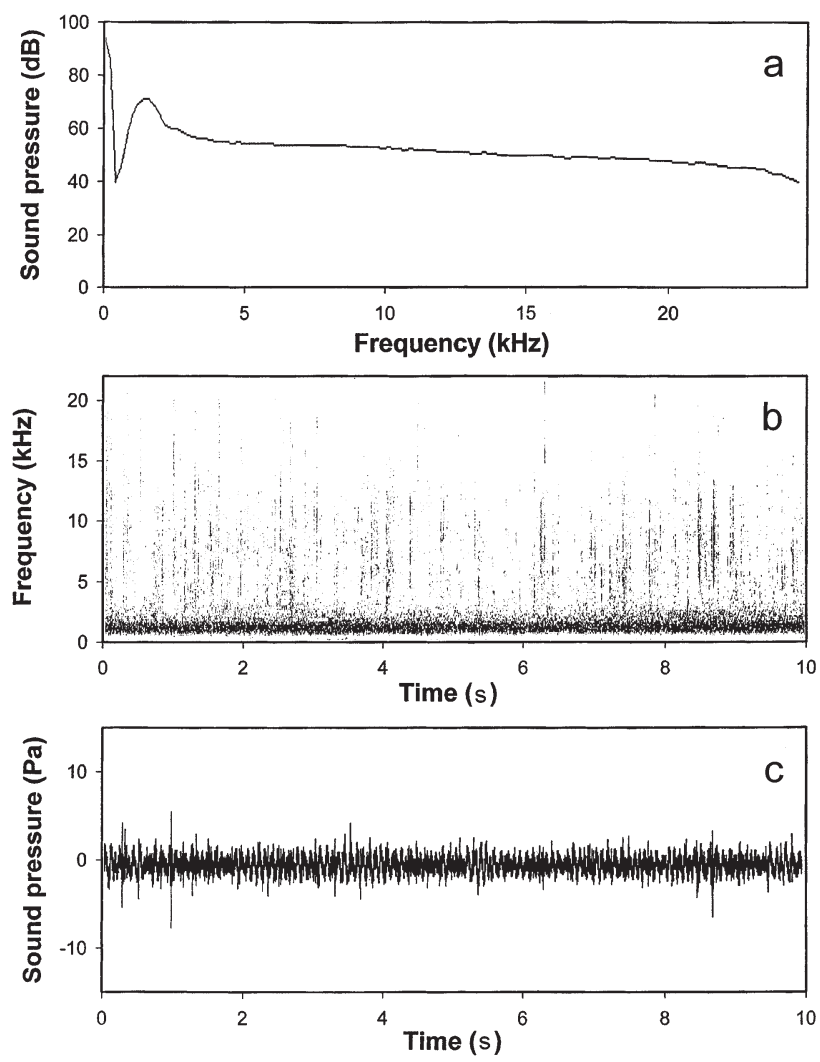

Fig. 3. Ambient underwater sound recorded at Ti Point approximately $200 \mathrm{~m}$ from shore. Recordings were made at 21:45 h, 20 February 1999. (a) Spectra; (b) spectrogram; (c) waveform. The data show a band of sounds around $2 \mathrm{kHz}$ probably arising from sea urchin feeding, while the higher frequency pulses are probably snapping shrimp
Results. The sound from Ti Point Reef was typical of evening chorus recordings from elsewhere in northern New Zealand and other locations (Tait 1962, Cato 1980) (Fig. 3). The peak of sound around $2 \mathrm{kHz}$ is thought to be due to sea urchin feeding, while the higher frequency pulses are probably snapping shrimp (Tait 1962, Cato 1980).

We caught fish larvae of primarily 2 taxa. Triplefins (Tripterygiidae) are benthic reef fishes that one would expect to be attracted to reefs. These triplefins were primarily Fosterygion spp. Only a few specimens (8, $<2 \%$ ) were positively identified as either Ruanoho (Gilloblenius?) spp. or Notoclinus spp., which is consistent with previous results for this area and time of year (Tricklebank et al. 1992). With counts this low, the data are not meaningful at the genus level given the variation in the catches. Instead, we chose to examine the triplefins as a group.

Pilchard (Clupeidae, Sardinops neopilchardus) are pelagic fishes that one would not expect to be attracted to reefs or to the sound emanating from a reef. Other species were caught in numbers too low for meaningful analysis: Kathetostoma giganteum (Uranoscopidae) (1), Acanthoclinus spp. (Plesiopidae) (5), Parika scaber (Monocanthidae) (7), Notolabrus celidotus (Labridae) (4) and Trachurus spp. (Carangidae) (11).

The response of triplefin and pilchard larvae differed markedly. Sound traps caught $86 \%$ (560) of all triplefin larvae, while only $14 \%$ (90) were caught in the silent traps (Fig. 4). When we paired traps within nights, sound traps caught more triplefin larvae than did silent traps (Fig. 5a, Wilcoxon signed-ranks test, $Z=2.08$, p < 0.05). Examined slightly differently, a sound trap

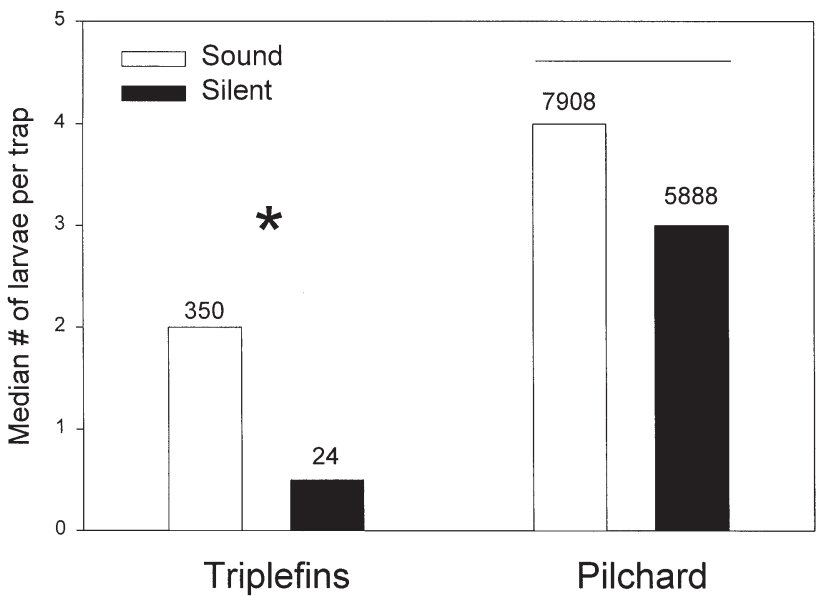

Fig. 4. Median number of fish larvae caught per trap per night for sound and silent treatments over 14 nights $(\mathrm{n}=27)$. Numbers over bars $=$ range (and maximum, as minimum number was 0 for all treatments); $\star p<0.05$; horizontal line indicates treatments that could not be distinguished statistically (Wilcoxon signed-ranks test) 

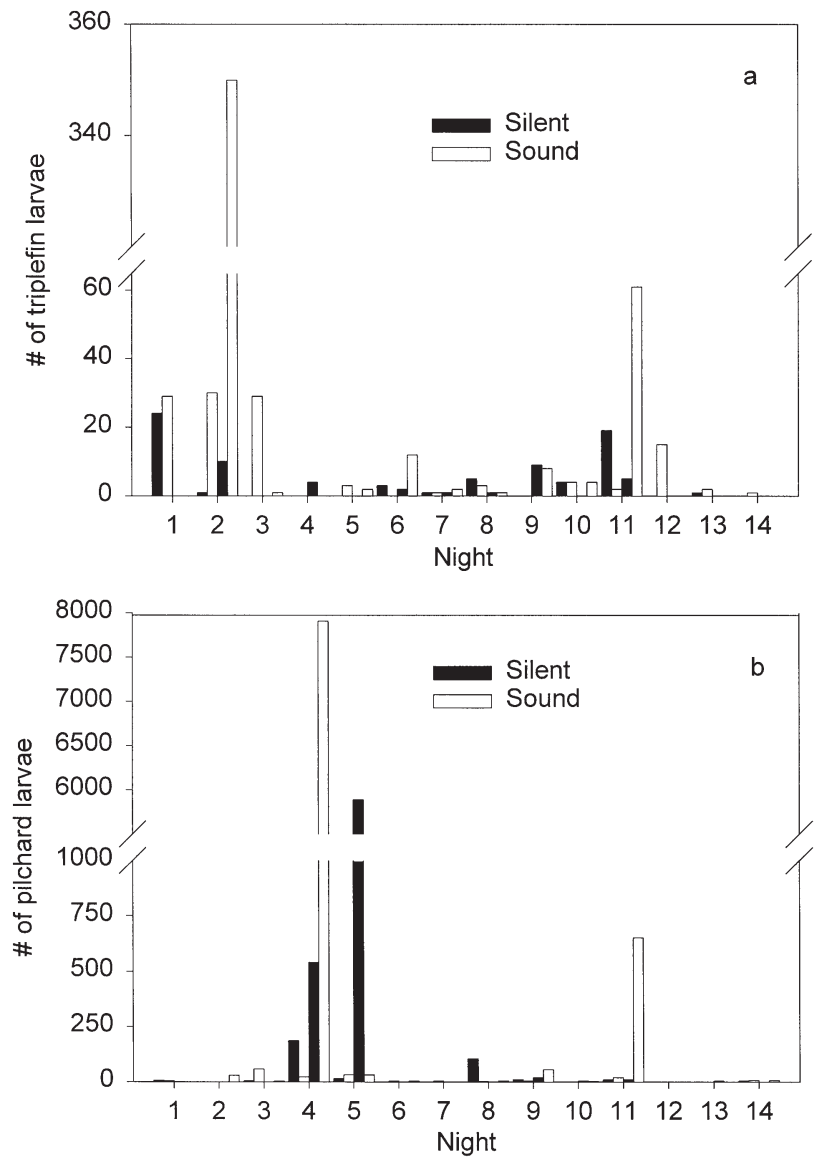

Fig. 5. Number of (a) triplefin and (b) pilchard larvae caught from sound and silent light-traps per night. Data are arranged in pairs. Pairs ( 1 sound/1 silent) to the left of an $x$-axis tick represent traps at the back of the bay; pairs to the right of a tick represent traps at the front of the bay. The experimental nights were not consecutive, but consisted of nights when weather permitted deployment of the experimental apparatus. Trials 1 to 3 and 11 to 13 occurred on or within several nights of the first quarter moon

caught more larvae than its paired silent trap on 14 of 19 occasions (ties of 0 excluded), which was more often than would be expected at random $(G$-test, $\mathrm{df}=1, G=$ $4.39, \mathrm{p}<0.05)$. There was high variation in the abundance of triplefin larvae among nights, with catches ranging from 0 to 350 larvae in the sound traps and 0 to 24 larvae in the silent traps.

Overall, the median size of triplefin larvae in sound traps $(20.01 \mathrm{~mm}$ standard length, $\mathrm{SL}$, range $=18.38)$ was greater than that of larvae in silent traps (19.34 mm SL, range 14.02) when data were pooled across nights (Mann-Whitney $U$-test, $H=11161, \mathrm{df}=1$, $\left.\chi^{2}=6.574, \mathrm{p}<0.05\right)$. However, there was no difference in the shape of the size (SL) distributions (KolmogorovSmirnov test, $p>0.05$, Fig. 6a,b). The slightly larger size of triplefin larvae in sound traps appears to have been due to the large catches on Night 2 (Fig 5a).
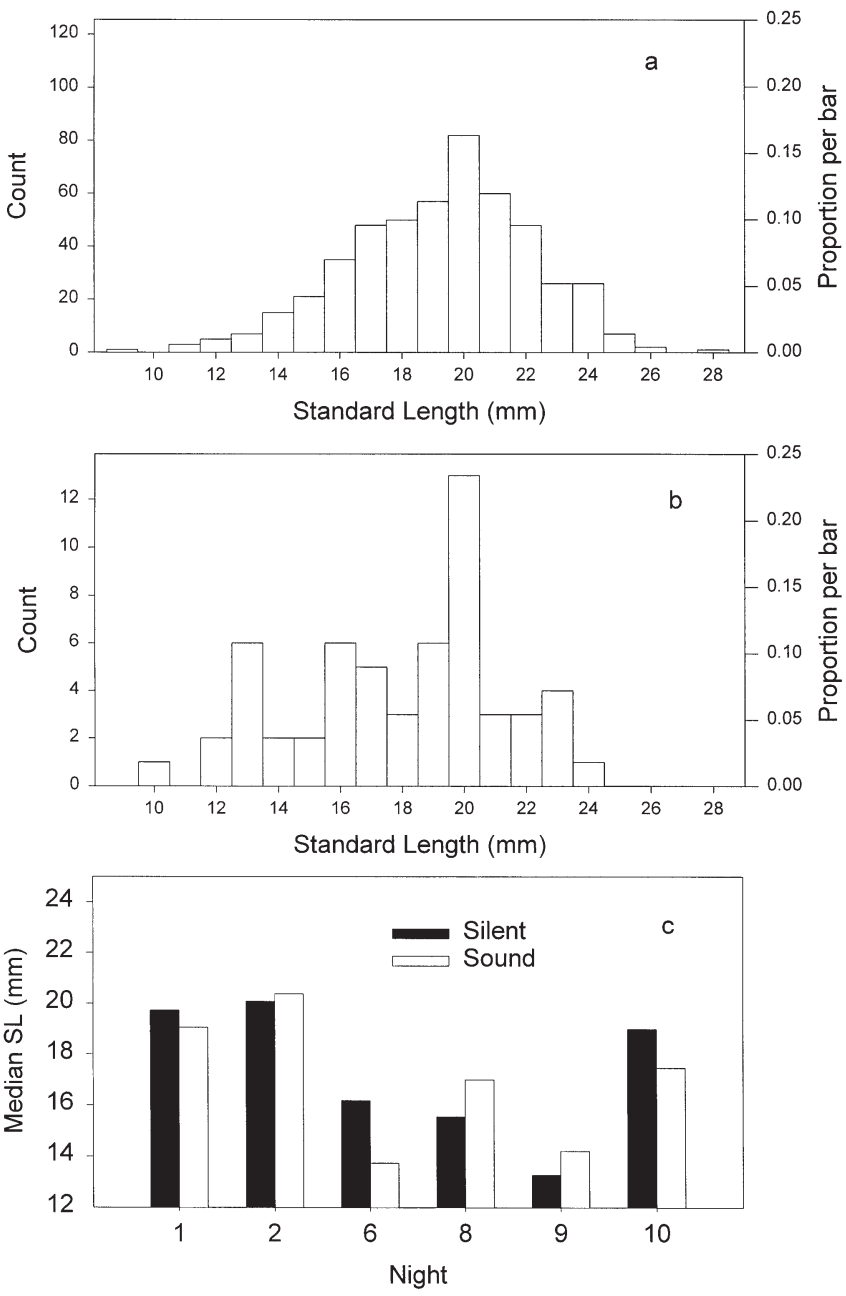

Fig. 6. Size distributions for triplefin larvae from (a) sound traps and (b) silent traps pooled across nights, and (c) median standard length in sound and silent traps for 6 nights

When examined by night, there was no effect of treatment on median size (Scheirer-Ray-Hare test, $\mathrm{df}=1$, $\mathrm{SS}=17926, H=0.99, \mathrm{p}>0.05$, Fig 6c). However, median size did differ among nights (Scheirer-RayHare test, $\mathrm{df}=5, \mathrm{SS}=727403, H=40.27, \mathrm{p}<0.001$ ). There was no interaction between nights and treatment (Scheirer-Ray-Hare test, $\mathrm{df}=4, \mathrm{SS}=31800, H=$ $1.76, \mathrm{p}>0.05)$. The mode for both treatments was $20 \mathrm{~mm}$ SL (Fig. 6a,b), approximately the size at settlement for triplefins (Willis 1994).

Pilchard larvae did not show a response to reef sound (Fig. 4). Sound traps caught 8847 (57\%) pilchard larvae, while silent ones caught 6801 (43\%). When we compared pairs of traps within nights, there was no significant difference between the sound and silent treatments (Fig. 5b, Wilcoxon signed-ranks test, $Z=$ $0.59, p>0.05$ ). Likewise, a sound trap caught more pilchard larvae than its paired silent trap on only 14 
of 25 comparisons, which did not differ from random ( $G$-test, df =1, $G=1.10, \mathrm{p}>0.05$ ). Catches of pilchard were highly variable both among and within nights, with catches ranging from 0 to 7908 larvae per trap for sound traps and 0 to 5888 larvae for silent traps.

Discussion. The results of this field experiment provide the first evidence that sound may be an important navigational cue in aquatic environments. Triplefin larvae were attracted to reef sound while the larvae of pilchards were not. Conducting the experiment in the field demonstrates that the attraction of triplefin larvae functions in the natural environment and at spatial scales relevant to the settlement of reef fishes.

Our data also indicate that the lunar cycle may be important in determining the level of response by larval fish to reef sound. Sampling Nights 1 to 3 and 11 to 13 occurred on or within several nights of the first quarter moon. These nights had the largest differences between sound and silent traps, as well as the highest catches of triplefin larvae. Notably, sound traps almost always caught more triplefin larvae than silent traps during this phase of the moon (8 of 9 comparisons). If data are pooled within nights, sound traps always caught more triplefin larvae during these nights (6 nights). The stronger patterns around the first quarter moon observed in our study may have been the result of greater availability of larvae (and therefore better resolution) or a change in larval behaviour (attraction to reef sound only when attempting to settle). However, Thorrold (1992) found that tidal currents may affect catches by moored light traps. Therefore, larvae may have been better able to swim to traps during neap tides when tidal currents are lower.

Aside from the triplefins and pilchard, the traps in this study caught few other species. The low numbers and small range of other species are due partly to the timing of larval supply and partly to the placement of light traps. In New Zealand, most taxa are more abundant in the summer (January to March) (Tricklebank et al. 1992, Hickford \& Schiel 1999). However, some triplefins (Fosterygion spp.) and pilchard larvae are most abundant in June and July, with reduced numbers through October (Tricklebank et al. 1992). Traps from other locations nearer reefs that were fished simultaneous with those in this study caught a greater number of the other species, especially Trachurus spp. and Parika scaber (Tolimieri unpubl. data), in addition to triplefins and pilchard. The placement of light traps in a sandy bay may, therefore, have reduced the actual larval supply to these traps.

The data on size differences of triplefin larvae between treatments are ambiguous. While there was an overall (pooled) difference in median size, this difference was due to the large sample in 1 sound trap on Night 2, which may have been coincidental. When analysed by night, the difference was not consistent, but sample sizes on other nights were much smaller. Ontogenetic differences in larval distribution (Leis 1991, Leis \& Reader 1991, Smith 2000) and habitat selection at settlement (Danilowicz 1997) have been noted before, so the subject merits future study.

At present, we do not know which component of the reef sound attracted the triplefin larvae. Much of the sound from our recording of a reef is biological in origin, probably produced by snapping shrimp and sea urchins (Tait 1962, Cato 1980). Fish larvae may be attracted to sound of biological origin because it indicates a suitable 'healthy' reef environment. If fish larvae are attracted to biological sound generated on the reef, this may have implications for conservation and management of 'noisy' reef species such as urchins. Furthermore, in many coastal areas human activities, such as shipping, have come to dominate the underwater acoustic spectra, which may also have biological consequences. Researchers, especially in the aquatic environment, have largely overlooked the potential of ambient sound as a source of orientation information for animals. While this study points to the importance of ambient sound to reef fish larvae, further research is required to elucidate the role of this cue among reef fishes in general as well as for other taxa.

Acknowledgements. We thank M. Birch, T. Wustenburg, B. Doak, B. Dudley, J. Schimanski, T. Langlois, F. Giambartolomei, N. Managh, D. Snell, V. Stamp, B. Dylan, M. Morganfield and A. Cozens for logistic support. S. Dawson kindly loaned the hydrophone. B Danilowicz, P. Levin, P. Sale, T. Willis and 4 anonymous reviewers provided useful discussion and comments. This work was supported by the Foundation for Research, Science and Technology, a University of Auckland postdoctoral fellowship (to N.T.), and the Marsden Committee.

\section{LITERATURE CITED}

Berhold P (1991) Orientation in birds. Birhauser-Verlag, Boston

Bowen BW, Meylan AB, Avise JC (1989) An odyssey of the green sea turtle: Ascension Island revisited. Proc Natl Acad Sci USA 86:573-576

Cato DH (1980) Some unusual sounds of apparent biological origin responsible for sustained background noise in the Timor Sea. J Acoust Soc Am 68:1056-1060

Charif RA, Mitchell S, Clark CW (1995) Canary 1.2 user's manual. Cornell Laboratory of Ornithology, Ithaca, NY

Danilowicz BS (1997) The effects of age and size on habitat selection during settlement of a damselfish. Environ Biol Fish 50:257-265

Doherty PJ (1987) Light-traps: selective but useful devices for quantifying the distributions and abundances of larval fishes. Bull Mar Sci 41:423-431

Hamilton PV, Russell BJ (1982) Field experiments on the sense organs and directional cues involved in offshore-oriented swimming by Aplysia brasiliana Rang (Mollusca: Gastropoda). J Exp Mar Biol Ecol 56:123-143 
Herrnkind W, Kanciruk P (1978) Mass migration of spiny lobster, Panulirus argus (Crustacea: Palinuridae): synopsis and orientation. In: Schmidt-Koenig K, Keeton WT (eds) Animal migration, navigation, and homing. Springer-Verlag, New York, p 430-439

Hickford MJH, Schiel DR (1999) Evaluation of the performance of light traps for sampling fish larvae in inshore temperate waters. Mar Ecol Prog Ser 186:293-302

Hobson KA (1998) Natal origins of migratory monarch butterflies at wintering colonies in Mexico: new isotopic evidence. Proc Natl Acad Sci USA 95:15436-15439

Jones GP, Milicich MJ, Lunow C (1999) Self-recruitment in a coral reef fish population. Nature 402:802-804

Leis JM (1991) The pelagic stage of reef fishes: the larval biology of coral reef fishes. In: Sale PF (ed) The ecology of fishes on coral reefs. Academic Press, Inc, San Diego

Leis JM, Carson-Ewart BM (1997) In situ swimming speeds of the late pelagic larvae of some Indo-Pacific coral-reef fishes. Mar Ecol Prog Ser 159:165-174

Leis JM, Carson-Ewart BM (1999) In situ swimming and settlement behavior in a Indo-Pacific coral-reef fish, the coral trout Plectropomus leopardus. Mar Biol 134:51-64

Leis JM, Reader SE (1991) Distributional ecology of larval milkfish, Chanos chanos (Pisces, Chanidae), in the Lizard Island region. Environ Biol Fish 30:395-405

Leis JM, Sweatman HPA, Reader SE (1996) What the pelagic stages of coral reef fishes are doing out in blue water: daytime field observations of larval behavioural capabilities. Mar Freshw Res 47:401-411

Lobel PS (1992) Sounds produced by spawning fishes. Environ Biol Fish 33:351-358

McCauley RD (1994) Distribution and levels of snapping shrimp noise in northern Australia. Report for the Defence Science and Technology Organization

McCauley RD (1995) Aspects of marine biological sound in Northern Australia. III. Reef associated fish choruses. Report for the Defence Science and Technology Organization

McKeown BA (1984) Fish migration. Croom Helm, London

Myrberg AA, Mohler M, Catala JD (1986) Sound production by males of a coral reef fish (Pomacentrus partitus): its significance to females. Anim Behav 34:913-923

Popper AN, Carlson TJ (1998) Application of sound and other stimuli to control fish behavior. Trans Am Fish Soc 127: 673-707

Richardson JW, Greene CR, Malme CI, Thomson DH (1995) Marine mammals and noise. Academic Press, San Diego

Rogers PH, Cox M (1988) Underwater sound as a biological

Editorial responsibility: Otto Kinne (Editor),

Oldendorf/Luhe, Germany stimulus. In: Atema J, Fay RR, Popper AN, Tavolga WN (eds) Sensory biology of aquatic animals. Springer-Verlag, New York, p 131-150

Roughgarden J, Gaines S, Possingham H (1988) Recruitment dynamics in complex life cycles. Science 241:1460-1466

Sale PF (1980) The ecology of fishes on coral reefs. Oceanogr Mar Biol Annu Rev 18:367-421

Smith KA (2000) Active and passive dispersal of Centroberyx affinis (Berycidae) and Gonorynchus greyi (Gonorynchidae) larvae on the Sydney shelf. Mar Freshw Res 51:229-234

Sokal RR, Rohlf FJ (1995) Biometry. The principles and practice of statistics in biological research, 3rd edn. WH Freeman \& Co, New York

Sponaugle S, Cowen RK (1994) Larval distributions and recruitment patterns of two Caribbean gobies (Gobiidae): contrasting early life histories in demersal spawners. Mar Biol 120:133-143

Stobutzki IC, Bellwood DR (1997) Sustained swimming abilities of the late pelagic stages of coral reef fishes. Mar Ecol Prog Ser 149:35-41

Stobutzki IC, Bellwood DR (1998) Nocturnal orientation to reefs by late pelagic stage coral reef fishes. Coral Reefs 17 : $103-110$

Swartz SL, Jones ML, Goodyear J, Withrow DE, Miller RV (1987) Radio-telemetric studies of gray whale migration along the California coast: a preliminary comparison of day and night migration rates. Rep Int Whal Commn 37: 295-299

Swearer SE, Caselle JE, Lea DW, Warner RR (1999) Larval retention and recruitment in an island population of coralreef fish. Nature 402:799-802

Tait RI (1962) The evening chorus: a biological noise investigation. Naval Research Laboratory, MHNZ Dockyard, Auckland

Thorrold SR (1992) Evaluating the performance of light traps for sampling small fish and squid in open water of the central Great Barrier Reef lagoon. Mar Ecol Prog Ser 89: $277-285$

Thorson G (1950) Reproductive and larval ecology of marine bottom invertebrates. Biol Rev 25:1-45

Tricklebank KA, Jacoby CA, Montgomery JC (1992) Composition, distribution and abundance of neustonic ichthyoplankton off Northeastern New Zealand. Estuar Coast Shelf Sci 34:263-275

Willis TJ (1994) The ecology and reproductive biology of Ericentrus rubrus (Clinidae), with an assessment of rockpool fish community structure. Masters thesis, University of Wellington

Submitted: February 28, 2000; Accepted: June 22, 2000

Proofs received from author(s): October 25, 2000 